\title{
METODE PEMBELAJARAN SISTEM PAKAR DIAGNOSA PENYAKIT IKAN HIAS AIR TAWAR PADA SMK NEGERI 2 TANGERANG
}

\author{
Herowati $^{1}$ \\ Agung Pambudi ${ }^{2}$ \\ Nurbayti $i^{3}$ \\ STMIK Raharja Jurusan Teknik Informatika ${ }^{1,2,3}$ \\ Jl. Jendral Sudirman No. 40, Modern Cikokol, Tangerang ${ }^{1,2,3}$ \\ Email : hera@ raharja.info ${ }^{3)}$, agung.pambudi@ raharja.info ${ }^{2)}$, nurbayti@raharja.info $^{3)}$
}

\begin{abstract}
ABSTRAK
Pendidikan di Indonesia pada saat ini sudah berkembang, sudah banyak bidang-bidang ilmu yang terlihat biasa tetapi sangat berguna jika dipelajari, contohnya ilmu dibidang budidaya perikanan, salah satu yang dapat dibudidayakan yaitu ikan hias air tawar, ikan hias ini sangat banyak digemari oleh para penggemar ikan hias. Tidak mudah memelihara dan merawat ikan hias air tawar ini, banyak sekali kendala yang disebabkan oleh faktor penyakit, lingkungan yang kurang bersih dan organisme yang hidup disekitarnya, kemungkinan terburuk dari ikan yang terkena penyakit adalah kematian, hal tersebut sudah pasti sangat merugikan bagi para penjual dan para penggemar yang memelihara ikan hias air tawar tersebut. Metode pembelajaran untuk mendiagnosa penyakit ikan masih menggunakan cara manual yaitu dengan memeriksa ke laboratorium, hal tersebut membutuhkan waktu yang sangat lama, mendiagnosa gejala penyakit pada ikan membutuhkan keahlian seorang pakar yang ahli dibidang perikanan. Sistem pakar dibangun dengan mengadopsi kemampuan seorang pakar yang ahli dalam mendiagnosa penyakit ikan hias air tawar melalui gejala-gejala yang dihadapi. Fokus utama dari penelitian sistem pakar ini pada penyakit ikan hias air tawar, sistem pakar ini dibuat menggunakan pemrograman Microsoft Visual Basic dengan basis data Microsoft Access, sistem ini menggunakan Metode Backward Chaining dengan Teknik Breadth-First Search, yaitu pencarian dengan cara menelusuri masalah secara mendalam sampai ditemukannya suatu solusi yang maksimal. Output dari sistem ini diharapkan dapat membantu para penjual, para penggemar ikan hias, ataupun para pelajar yang sedang mempelajari tentang ikan hias air tawar untuk mendiagnosa penyakit, dan juga memberikan solusi atau cara penanganan dari penyakit ikan hias air tawar secara cepat, tepat dan akurat.
\end{abstract}

Kata Kunci: Sistem Pakar, Ikan Hias Air Tawar, Microsoft Visual Basic, Backward Chaining.

\begin{abstract}
The year 1830, munculah called zoetrope, cylindrical object with empty spaces with pictures drawn by hand on the surface of it. While playing, the same motion effect. The year 1870, an inventor from France, Emile Reynaud added a mirror in the middle of the cylinder space. A few years later, he discovered the version of Windows will arise. By adding light reflector and lenses to magnify images on the screen. The year 1892, he did a demonstration in Paris's Theatre Optique, with hundreds of images using the hands to cause the effect of motion pictures for 15 minutes. Rouben Mamoulian, an American film director born in 1929 demonstrated various types of sound in a movie. This is then pushed the filmmaker makes the soft-spoken. The first film camera that uses a color separation. Technicolor Camera that was discovered in 1932 using the principle of "Three-strip" that divides the image into the three primary colors red, yellow, blue (cyan, magenta, yellow). This camera into movie production tool fullcolor using the principle of the "three-strip"
\end{abstract}

Keywords: Video, Multimedia 


\section{PENDAHULUAN}

Perkembangan teknologi di era globalisasi saat ini semakin mengalami kemajuan, setiap orang pasti membutuhkan komputer untuk membantu pekerjaan sehari-hari dan juga sangat berguna dibidang pendidikan untuk membantu sistem pembelajaran selain itu komputer menjadi salah satu kebutuhan yang sangat penting karena komputer dapat di akses dengan cepat dan mudah. Komputer juga menjadi alat bantu penyelesaian masalah-masalah yang dihadapi manusia, sistem komputer yang dapat menyimpan data dengan jumlah yang sangat besar dan dapat mencari data yang tersimpan dengan cepat. Ada juga yang menjadikan komputer sebagai alat pemberi pertimbangan dalam menentukan suatu masalah-masalah yang sedang dihadapi. Salah satu contoh ilmu komputer yang dimanfaatkan oleh manusia untuk mempermudah pekerjaannya yaitu dengan membentuk sistem pakar yang merupakan salah satu ilmu dibidang kecerdasan buatan. Kecerdasan buatan adalah kegiatan komputer dengan kemampuan untuk menampilkan perilaku yang dianggap cerdas jika dilihat oleh manusia.

Salah satu pemanfaatan sistem pakar yaitu dalam bidang budidaya perikanan, dengan adanya sistem pakar pada budidaya perikanan dapat membantu seorang untuk mengetahui jenis-jenis penyakit dan penyebabnya, juga dapat memberikan konsultasi sampai memberikan saran penentuan solusi dari hasil yang ditemukan.

\section{TINJAUAN PUSTAKA}

Menurut Tata Sutabri (2012:10), "Secara sederhana suatu sistem dapat diartikan sebagai suatu kumpulan atau himpunan dari unsur, komponen atau variable yang terorganisir, saling berinteraksi, saling tergantung satu sama lain dan terpadu".

Menurut Yakub (2012:142), "Analisa sistem dapat diartikan sebagai suatu proses untuk memahami sistem yang ada, dengan menganalisa jabatan dan uraian tugas (business users), proses bisnis (business prosess), ketentuan atau aturan (business rule), masalah dan mencari solusinya (business problem and business soulution), dan rencana-rencana perusahaan (business plan)".

\section{HASIL DAN PEMBAHASAN}

Ikan merupakan salah satu makanan berprotein yang di konsumsi manusia, jika terdapat hama atau penyakit yang dialami oleh ikat tersebut maka akan mempengaruhi tumbuh kembang ikan, salah satu faktor yang mempengaruhi pertumbuhan ikan maupun perkembangbiakannya yaitu terganggunya kondisi lingkungan dan organisme penyebab penyakit, oleh karena itu dengan adanya aplikasi sistem pakar dalam budidaya perikanan, dapat membantu menyelesaikan dan memberikan solusi dari masalah-masalah yang dihadapi.

\section{Diagram Rancangan Sistem}

Untuk menganalisa sistem berjalan, penelitian ini menggunakan Flowchart untuk menggambarkan prosedur dan proses yang berjalan. 


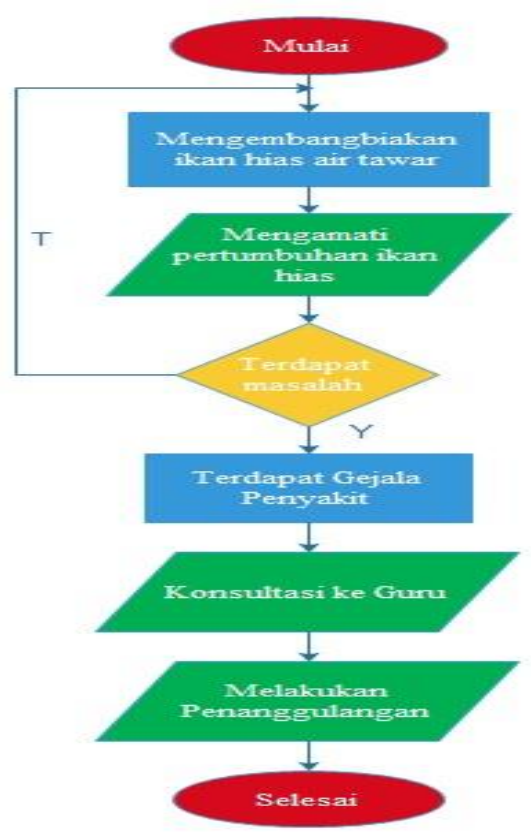

Gambar 1 Flowchart konsutlasi individu yang berjalan pada Siswa

Pada Gambar 1 diatas dapat di jelaskan bahwa siswa di berikan tugas untuk mengembangbiakan ikan hias air tawar, setelah itu siswa mengamati pertumbuhan ikan hias setiap hari, jika mengalami masalah pada pertumbuhan ikan yang di sebabkan oleh gejala penyakit maka siswa dapat berkonsultasi kepada guru yang ada dibidangnya, dan jika pertumbuhan ikan tidak mengalami masalah siswa dapat kembali mengamati setiap pertumbuhan ikan hias dalam proses perkembangbiakan nya.

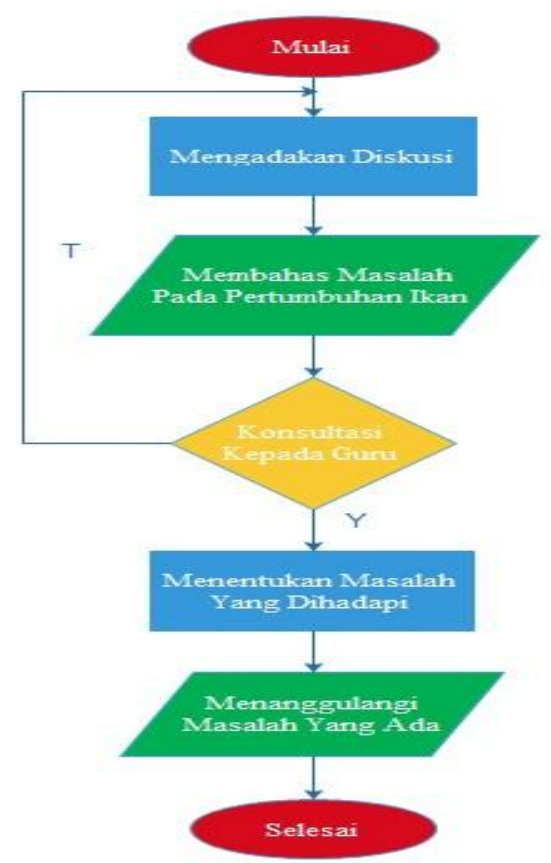

Gambar 2 Flowchart konsutlasi Kelompok yang berjalan pada Siswa

Pada Gambar 2 diatas dapat di jelaskan bahwa siswa mengadakan diskusi dengan kelompoknya, dalam diskusi tersebut siswa membahas masalah yang muncul pada pertumbuhan ikan yang sedang dikembangbiakan, jika siswa tidak berkonsultasi kepada guru 
maka siswa dapat melanjutkan kembali diskusi nya, dan jika siswa berkonsultasi kepada guru maka selanjut nya siswa dan guru menentukan masalah yang dihadapi pada ikan hias tersebut, lalu menanggulangi masalah yang ada.

\section{Rancangan Tampilan yang diusulkan}

Desain Menu Utama

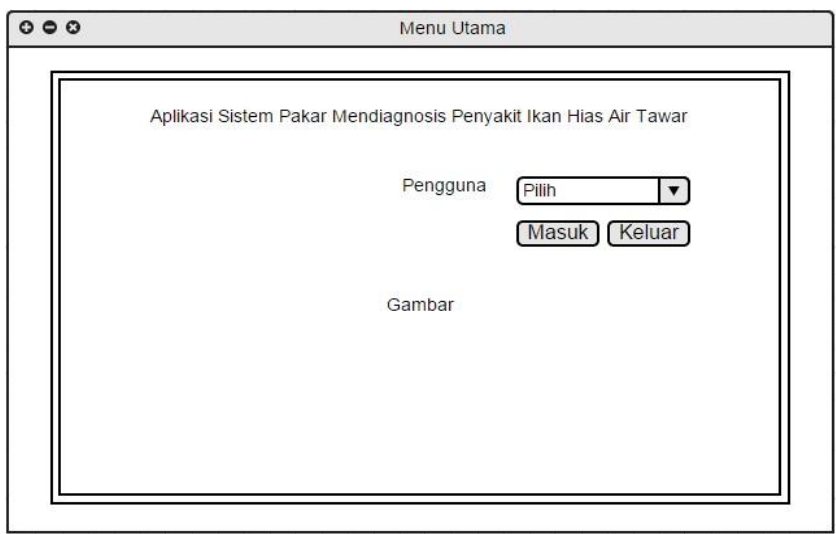

Gambar 3 Prototype Menu Utama

\begin{tabular}{|c|l|c|l|}
\hline No & \multicolumn{1}{|c|}{ Komponen } & Caption & \multicolumn{1}{|c|}{ Fungsi } \\
\hline 1 & Label & Judul & $\begin{array}{l}\text { Untuk informasi judul } \\
\text { program }\end{array}$ \\
\hline 2 & Label & Pengguna & $\begin{array}{l}\text { Untuk informasi judul } \\
\text { program }\end{array}$ \\
\hline 3 & Combo Box & Pilih & $\begin{array}{l}\text { Untuk memilih pengguna } \\
\text { yang akan mengakses }\end{array}$ \\
\hline 4 & Command Button & Masuk & $\begin{array}{l}\text { Untuk proses ke menu } \\
\text { pengguna }\end{array}$ \\
\hline 5 & Command Button & Keluar & $\begin{array}{l}\text { Untuk proses keluar } \\
\text { program }\end{array}$ \\
\hline
\end{tabular}

Gambar 4 Tabel Keterangan Prototype Menu Utama

Tampilan Menu Siswa

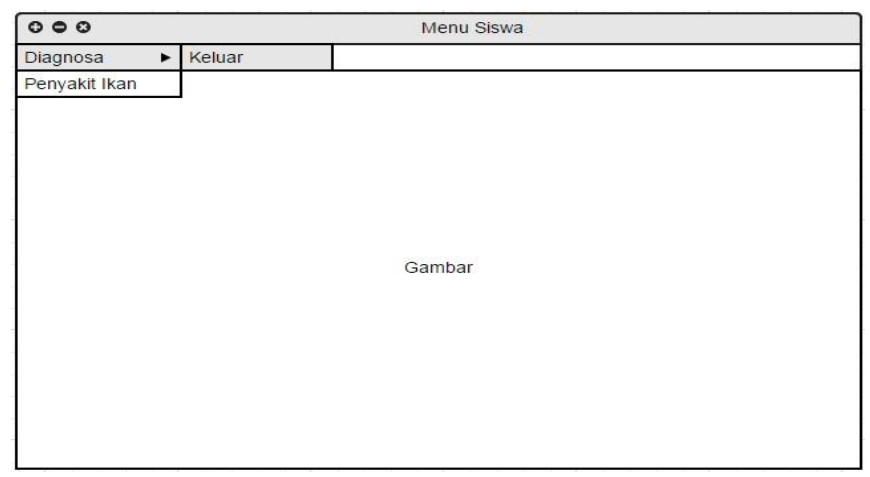

Gambar 5 Prototype Menu Siswa 


\begin{tabular}{|c|l|c|l|}
\hline No & Komponen & Caption & \multicolumn{1}{|c|}{ Fungsi } \\
\hline 1 & Menu Bar & Diagnosa & $\begin{array}{l}\text { Untuk menampilkan sub } \\
\text { menu }\end{array}$ \\
\hline 2 & Sub Menu & Penyakit Ikan & $\begin{array}{l}\text { Untuk proses ke menu } \\
\text { diagnosa }\end{array}$ \\
\hline 3 & Menu Bar & Keluar & $\begin{array}{l}\text { Untuk proses keluar } \\
\text { program }\end{array}$ \\
\hline
\end{tabular}

Gambar 6 Tabel Keterangan Prototype Menu Siswa

Tampilan Menu Guru

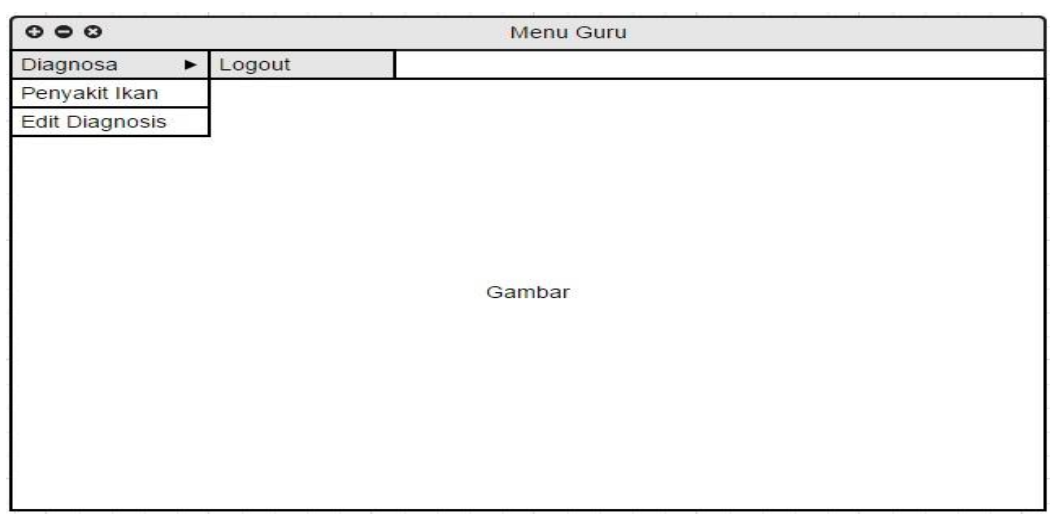

Gambar 7 Prototype Menu Guru

\begin{tabular}{|c|l|c|l|}
\hline No & \multicolumn{1}{|c|}{ Komponen } & Caption & \multicolumn{1}{|c|}{ Fungsi } \\
\hline 1 & Menu Bar & Diagnosa & $\begin{array}{l}\text { Untuk menampilkan sub } \\
\text { menu }\end{array}$ \\
\hline 2 & Sub Menu & Penyakit Ikan & $\begin{array}{l}\text { Untuk proses ke menu } \\
\text { diagnosa }\end{array}$ \\
\hline 3 & Sub Menu & Edit Diagnosis & $\begin{array}{l}\text { Untuk proses ke menu } \\
\text { edit diagnosa }\end{array}$ \\
\hline 4 & Menu Bar & Logout & $\begin{array}{l}\text { Untuk proses keluar } \\
\text { program }\end{array}$ \\
\hline
\end{tabular}

Gambar 8 Tabel Keterangan Prototype Menu Guru

Tampilan Menu Admin

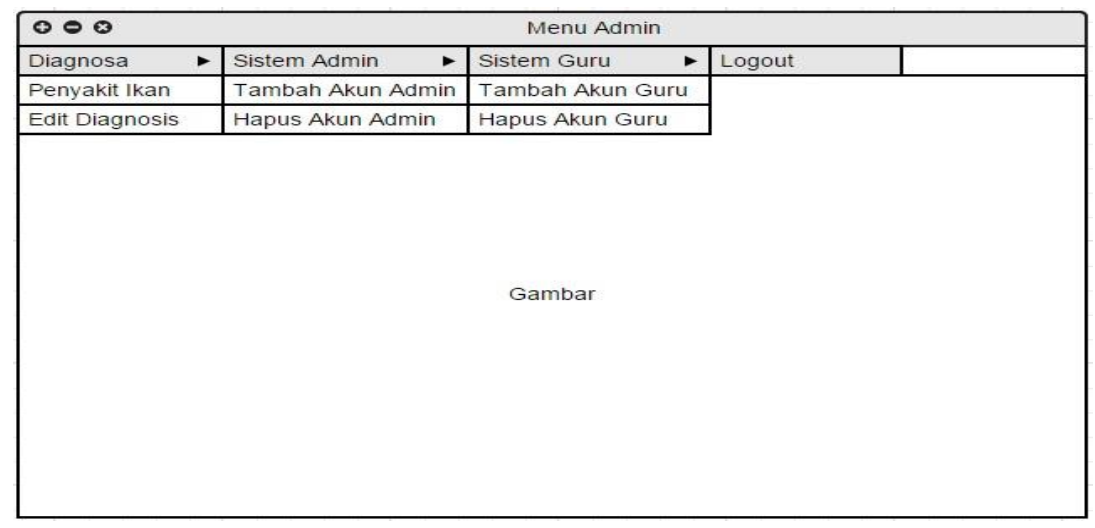

Gambar 9 Prototype Menu Admin 


\begin{tabular}{|c|l|c|l|}
\hline No & \multicolumn{1}{|c|}{ Komponen } & Caption & \multicolumn{1}{|c|}{ Fungsi } \\
\hline 1 & Menu Bar & Diagnosa & $\begin{array}{l}\text { Untuk menampilkan sub } \\
\text { menu }\end{array}$ \\
\hline 2 & Sub Menu & Penyakit Ikan & $\begin{array}{l}\text { Untuk proses ke menu } \\
\text { diagnosa }\end{array}$ \\
\hline 3 & Sub Menu & Edit Diagnosis & $\begin{array}{l}\text { Untuk proses ke menu } \\
\text { edit diagnosa }\end{array}$ \\
\hline 4 & Menu Bar & Sistem Admin & $\begin{array}{l}\text { Untuk menampilkan sub } \\
\text { menu }\end{array}$ \\
\hline 6 & Sub Menu & $\begin{array}{c}\text { TambahAkun } \\
\text { Admin }\end{array}$ & $\begin{array}{l}\text { Untuk proses ke menu } \\
\text { tambah akun admin }\end{array}$ \\
\hline 7 & Menu Bar & HapusAkun & $\begin{array}{l}\text { Untuk proses ke menu } \\
\text { hapus akun admin }\end{array}$ \\
\hline 8 & Sub Menu & Sistem Guru & $\begin{array}{l}\text { Untuk menampilkan sub } \\
\text { menu }\end{array}$ \\
\hline 9 & Sub Menu & $\begin{array}{c}\text { TambahAkun } \\
\text { Guru }\end{array}$ & $\begin{array}{l}\text { Untuk proses ke menu } \\
\text { tambah akun guru }\end{array}$ \\
\hline 10 & Menu Bar & HapusAkun & $\begin{array}{l}\text { Untuk proses ke menu } \\
\text { hapus akun guru }\end{array}$ \\
\hline
\end{tabular}

Gambar 10 Tabel Keterangan Prototype Menu Admin

Tampilan Menu Diagnosa

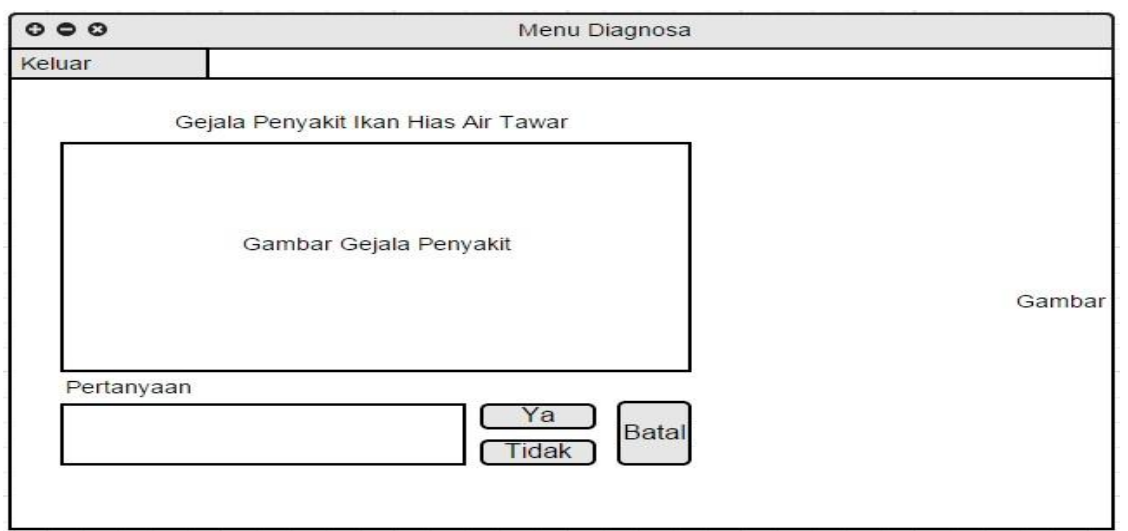

Gambar 11 Prototype Menu Diagnosa

\begin{tabular}{|c|l|c|l|}
\hline No & \multicolumn{1}{|c|}{ Komponen } & Caption & \multicolumn{1}{|c|}{ Fungsi } \\
\hline 1 & Menu Bar & Logout & $\begin{array}{l}\text { Untuk proses keluar } \\
\text { program }\end{array}$ \\
\hline 3 & Imabel & Judul & $\begin{array}{l}\text { Untuk informasi judul } \\
\text { diagnosa }\end{array}$ \\
\hline 4 & Label & ImageGejala & $\begin{array}{l}\text { Untuk menampilkan } \\
\text { gambar dari gejala }\end{array}$ \\
\hline 5 & Label & Pertanyaan & $\begin{array}{l}\text { Untuk informasi } \\
\text { pertanyaan dari gejala }\end{array}$ \\
\hline 6 & Command Button & - & $\begin{array}{l}\text { Untuk menampilkan id } \\
\text { gelaja }\end{array}$ \\
\hline 7 & Command Button & Ya & $\begin{array}{l}\text { Untuk proses } \\
\text { kepertanyaan berikutnya }\end{array}$ \\
\hline 8 & Command Button & Tidak & $\begin{array}{l}\text { Untuk proses } \\
\text { kepertanyaan berikutnya }\end{array}$ \\
\hline
\end{tabular}

Gambar 12 Tabel Keterangan Prototype Menu Diagnosa

Tampilan Hasil Diagnosa 


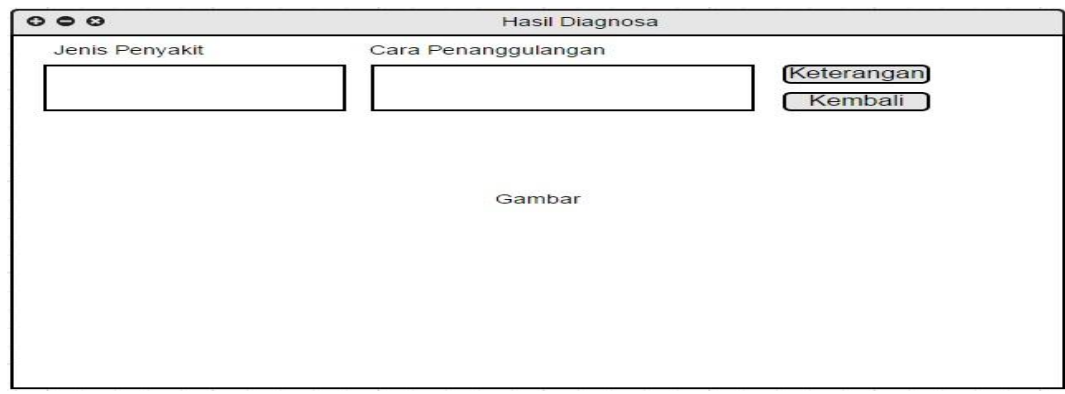

Gambar 13 Prototype Hasil Diagnosa

\begin{tabular}{|c|l|c|l|}
\hline No & \multicolumn{1}{|c|}{ Komponen } & Caption & \multicolumn{1}{|c|}{ Fungsi } \\
\hline 1 & Label & JenisPenyakit & $\begin{array}{l}\text { Untuk informasi judul } \\
\text { jenis penyakit }\end{array}$ \\
\hline 2 & Label & - & $\begin{array}{l}\text { Untuk menampilkan } \\
\text { jenis penyakit }\end{array}$ \\
\hline 3 & Label & $\begin{array}{c}\text { CaraPenanggul } \\
\text { angan }\end{array}$ & $\begin{array}{l}\text { Untuk informasi judul } \\
\text { cara penanggulangan }\end{array}$ \\
\hline 5 & Command Button & Keterangan & $\begin{array}{l}\text { Untuk menampilkan } \\
\text { cara penanggulangan } \\
\text { keterangan penyakit }\end{array}$ \\
\hline 6 & Command Button & Kembali & $\begin{array}{l}\text { Untuk proses kembali } \\
\text { ke menu diagnosa }\end{array}$ \\
\hline
\end{tabular}

Gambar 14 Tabel Keterangan Prototype Hasil Diagnosa

Tampilan Keterangan Penyakit

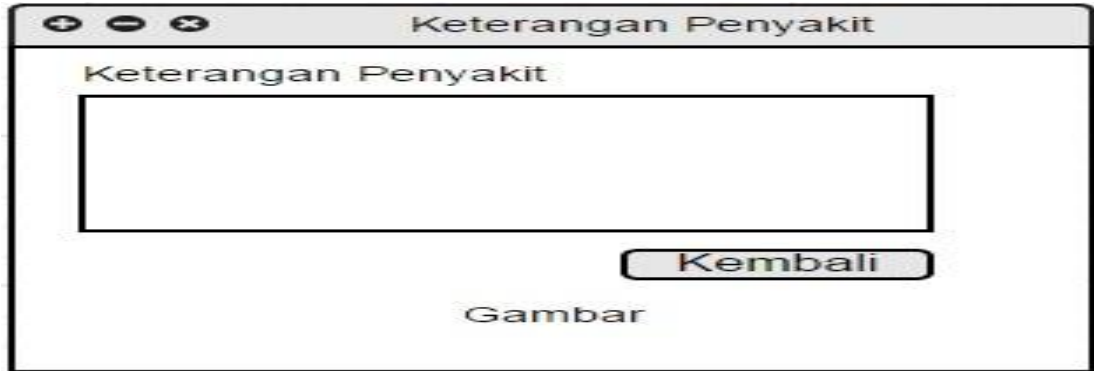

Gambar 15 Prototype Keterangan Penyakit

\begin{tabular}{|c|l|c|l|}
\hline No & \multicolumn{1}{|c|}{ Komponen } & Caption & \multicolumn{1}{c|}{ Fungsi } \\
\hline 1 & Label & $\begin{array}{c}\text { KeteranganPen } \\
\text { yakit }\end{array}$ & $\begin{array}{l}\text { Untuk informasi judul } \\
\text { keterangan penyakit }\end{array}$ \\
\hline 2 & Label & - & $\begin{array}{l}\text { Untuk menampilkan } \\
\text { keterangan dari penyakit }\end{array}$ \\
\hline 3 & Command Button & Kembali & $\begin{array}{l}\text { Untuk proses ke menu } \\
\text { hasil diagnosa }\end{array}$ \\
\hline
\end{tabular}

Gambar 16 Tabel Keterangan Prototype Keterangan Penyakit

Tampilan Menu Edit Penyakit

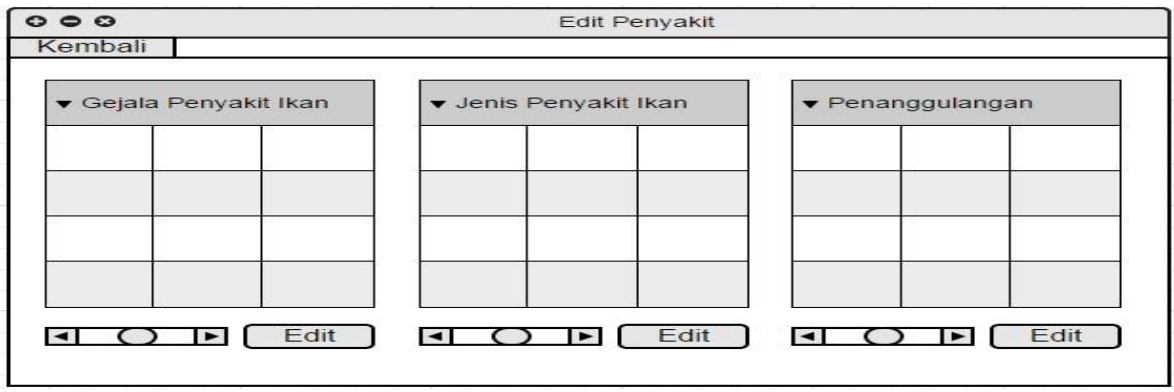

Gambar 17 Prototype Menu Edit Penyakit 


\begin{tabular}{|c|c|c|c|}
\hline No & Komponen & Caption & Fungsi \\
\hline 1 & Menu Bar & Kembali & Untuk proses kembali \\
\hline 2 & List Box & GejalaPenyakit & $\begin{array}{l}\text { Untuk menampilkan } \\
\text { daftar dari gejala }\end{array}$ \\
\hline 3 & H scroll Bar & - & $\begin{array}{l}\text { Untuk mengscroll daftar } \\
\text { gelaja }\end{array}$ \\
\hline 4 & Command Button & Edit & $\begin{array}{l}\text { Untuk proses ke menu } \\
\text { edit gejala }\end{array}$ \\
\hline 5 & List $\mathrm{Box}$ & JenisPenyakit & $\begin{array}{l}\text { Untuk menampilkan } \\
\text { daftar dari jenis }\end{array}$ \\
\hline 6 & H Scroll Bar & - & $\begin{array}{l}\text { Untuk mengscroll daftar } \\
\text { jenis penyakit }\end{array}$ \\
\hline 7 & Command Button & Edit & $\begin{array}{l}\text { Untuk proses ke menu } \\
\text { edit jenis penyakit }\end{array}$ \\
\hline 8 & List Box & $\begin{array}{c}\text { Penanggulanga } \\
\text { nPenyakit }\end{array}$ & $\begin{array}{l}\text { Untuk menampilkan } \\
\text { daftar dari } \\
\text { penanggulangan }\end{array}$ \\
\hline 9 & H scroll Bar & - & $\begin{array}{l}\text { Untuk mengscroll daftar } \\
\text { penanggulangan }\end{array}$ \\
\hline 10 & Command Button & Edit & $\begin{array}{l}\text { Untuk proses ke menu } \\
\text { edit penanggulangan }\end{array}$ \\
\hline
\end{tabular}

Gambar 18 Tabel Keterangan Prototype Menu Edit Penyakit

Tampilan Edit Gejala

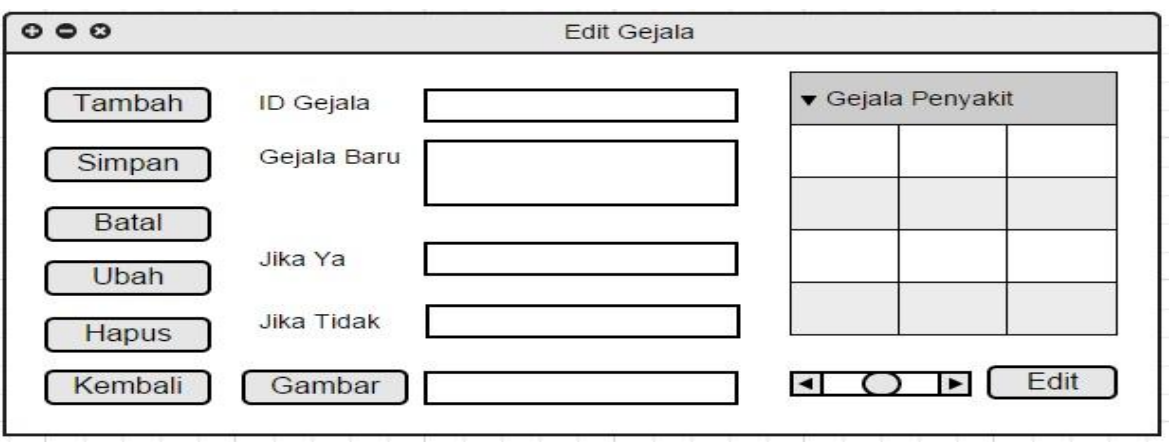

Gambar 19 Prototype Edit Gejala

\begin{tabular}{|c|c|c|c|}
\hline No & Komponen & Caption & Fungsi \\
\hline 1 & Command Button & Tambah & $\begin{array}{l}\text { Untuk proses tambah } \\
\text { gejala }\end{array}$ \\
\hline 2 & Command Button & Simpan & $\begin{array}{l}\text { Untuk proses simpan } \\
\text { gejala }\end{array}$ \\
\hline 3 & Command Button & Batal & $\begin{array}{l}\text { Untuk proses batal } \\
\text { menyimpan gejala }\end{array}$ \\
\hline 4 & Command Button & Ubah & $\begin{array}{l}\text { Untuk proses ubah } \\
\text { gejala. }\end{array}$ \\
\hline 5 & Command Button & Hapus & $\begin{array}{l}\text { Untuk proses hapus } \\
\text { gejala }\end{array}$ \\
\hline 6 & Command Button & Kembali & $\begin{array}{l}\text { Untuk proses kembali } \\
\text { ke menu edit }\end{array}$ \\
\hline 7 & Label & IDGejala & $\begin{array}{l}\text { Untuk menampilkan } \\
\text { informasi ID }\end{array}$ \\
\hline 8 & Label & GejalaBanu & $\begin{array}{l}\text { Untuk menampilkan } \\
\text { informasi gejala baru }\end{array}$ \\
\hline 9 & Labe1 & JikaYa & $\begin{array}{l}\text { Untuk menampilkan } \\
\text { informasi jika ya }\end{array}$ \\
\hline 10 & Labe1 & JikaTidak & $\begin{array}{l}\text { Untuk menampilkan } \\
\text { informasi jika tidak }\end{array}$ \\
\hline 11 & Command Button & Gambar & $\begin{array}{l}\text { Untuk proses upload } \\
\text { gambar dari gejala baru }\end{array}$ \\
\hline 12 & Text Box & - & $\begin{array}{l}\text { Untuk proses input id } \\
\text { gejala }\end{array}$ \\
\hline 13 & Text Box & - & $\begin{array}{l}\text { Untuk proses input } \\
\text { gejala baru }\end{array}$ \\
\hline 14 & Text Box & 一 & $\begin{array}{l}\text { Untuk proses input alur } \\
\text { jika menjawvab ya }\end{array}$ \\
\hline 15 & Text Box & - & $\begin{array}{l}\text { Untuk proses input alur } \\
\text { jika menjawab tidak }\end{array}$ \\
\hline 16 & Text Box & 一 & $\begin{array}{l}\text { Untuk informasi letak } \\
\text { storage dari gambar }\end{array}$ \\
\hline 17 & H Scroll Bar & - & $\begin{array}{l}\text { Untuk mengscroll daftar } \\
\text { gejala penyakit }\end{array}$ \\
\hline 18 & List Box & GejalaPenyakit & $\begin{array}{l}\text { Untuk menampilkan } \\
\text { daftar gejala }\end{array}$ \\
\hline
\end{tabular}

Gambar 20 Tabel Keterangan Prototype Edit Gejala 
Tampilan Edit Penyakit

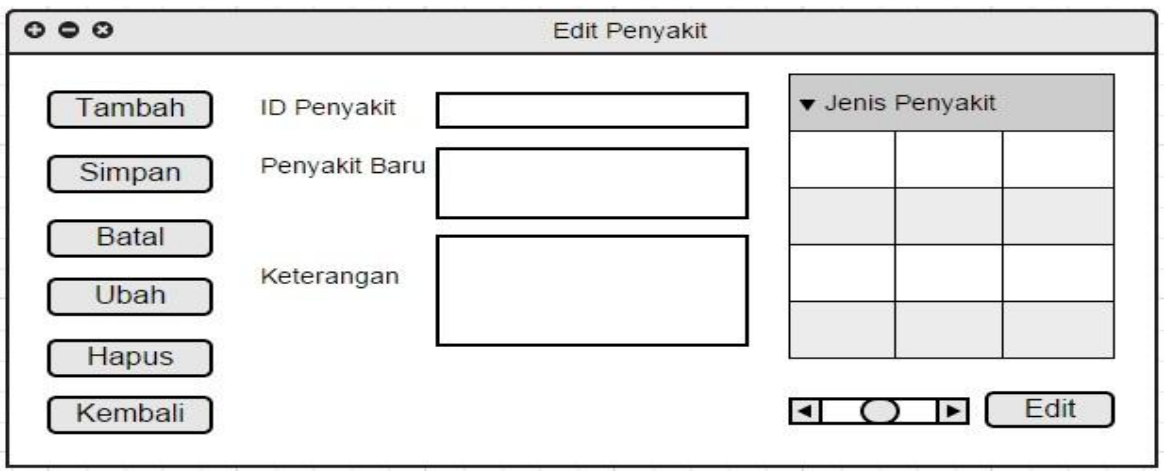

Gambar 21 Prototype Edit Jenis Penyakit

\begin{tabular}{|c|l|c|l|}
\hline No & Komponen & Caption & \multicolumn{1}{|c|}{ Fungsi } \\
\hline 1 & Command Button & Tambah & $\begin{array}{l}\text { Untuk proses tambah } \\
\text { gejala }\end{array}$ \\
\hline 3 & Command Button & Simpan & $\begin{array}{l}\text { Untuk proses simpan } \\
\text { gejala }\end{array}$ \\
\hline 4 & Command Button & Uatal & $\begin{array}{l}\text { Untuk proses batal } \\
\text { menyimpan gejala }\end{array}$ \\
\hline 5 & Command Button & Hapus & $\begin{array}{l}\text { Untuk proses ubah } \\
\text { gejala } \\
\text { gejala proses hapus }\end{array}$ \\
\hline 6 & Command Button & Kembali & $\begin{array}{l}\text { Untuk proses kembali } \\
\text { ke menu edit }\end{array}$ \\
\hline 7 & Label & IDPenyakit & $\begin{array}{l}\text { Untuk menampilkan } \\
\text { informasi ID }\end{array}$ \\
\hline 8 & Label & PenyakitBaru & $\begin{array}{l}\text { Untuk menampilkan } \\
\text { informasi penyakit baru }\end{array}$ \\
\hline 9 & Label & Keterangan & $\begin{array}{l}\text { Untuk menampilkan } \\
\text { informasi keterangan }\end{array}$ \\
\hline 10 & Text Box & $\begin{array}{l}\text { Untuk proses input id } \\
\text { penyakit }\end{array}$ \\
\hline 11 & Text Box & $\begin{array}{l}\text { Untuk proses input } \\
\text { penyakit baru }\end{array}$ \\
\hline
\end{tabular}

\begin{tabular}{|c|l|c|l|}
\hline 12 & Text Box & - & $\begin{array}{l}\text { Untuk proses input } \\
\text { keterangan penyakit }\end{array}$ \\
\hline 13 & H Scroll Bar & - & $\begin{array}{l}\text { Untuk mengscroll daftar } \\
\text { jenis penyakit }\end{array}$ \\
\hline 14 & List Box & GejalaPenyakit & $\begin{array}{l}\text { Untuk menampilkan } \\
\text { daftar jenis penyakit }\end{array}$ \\
\hline
\end{tabular}

Gambar 22 Tabel Keterangan Prototype Edit Jenis Penyakit

Tampilan Edit Penanggulangan

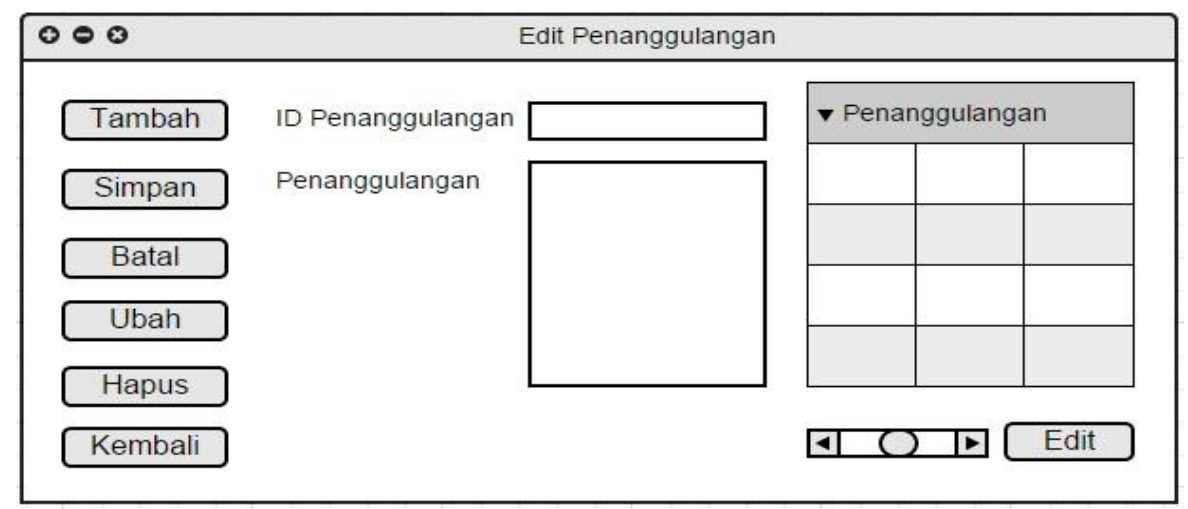

Gambar 23 Prototype Edit Penanggulangan 


\begin{tabular}{|c|c|c|c|}
\hline No & Komponen & Caption & Fungsi \\
\hline 1 & Command Button & Tambah & $\begin{array}{l}\text { Untuk proses tambah } \\
\text { gejala }\end{array}$ \\
\hline 2 & Command Button & Simpan & $\begin{array}{l}\text { Untuk proses simpan } \\
\text { gejala }\end{array}$ \\
\hline 3 & Command Button & Batal & $\begin{array}{l}\text { Untuk proses batal } \\
\text { menyimpan gejala }\end{array}$ \\
\hline 4 & Command Button & Ubah & $\begin{array}{l}\text { Untuk proses ubah } \\
\text { gejala }\end{array}$ \\
\hline 5 & Command Button & Hapus & $\begin{array}{l}\text { Untuk proses hapus } \\
\text { gejala }\end{array}$ \\
\hline 6 & Command Button & Kembali & $\begin{array}{l}\text { Untuk proses kembali } \\
\text { ke menu edit }\end{array}$ \\
\hline 7 & Label & $\begin{array}{c}\text { IDPenanggulan } \\
\text { gan }\end{array}$ & $\begin{array}{l}\text { Untuk menampilkan } \\
\text { informasi ID }\end{array}$ \\
\hline 8 & Label & $\begin{array}{c}\text { Penanggulanga } \\
\text { nbaru }\end{array}$ & $\begin{array}{l}\text { Untuk menampilkan } \\
\text { informasi } \\
\text { penanggulangan baru }\end{array}$ \\
\hline 10 & Text Box & - & $\begin{array}{l}\text { Untuk proses input id } \\
\text { penanggulangan }\end{array}$ \\
\hline 11 & Text Box & - & $\begin{array}{l}\text { Untuk proses input } \\
\text { penanggulangan baru }\end{array}$ \\
\hline 12 & H Scroll Bar & - & $\begin{array}{l}\text { Untuk mengscroll daftar } \\
\text { penanggulangan }\end{array}$ \\
\hline 13 & List $\mathrm{Box}$ & $\begin{array}{c}\text { Penanggulanga } \\
\text { n }\end{array}$ & $\begin{array}{l}\text { Untuk menampilkan } \\
\text { daftar penanggulangan }\end{array}$ \\
\hline
\end{tabular}

Gambar 24 Tabel Keterangan Prototype Edit Penanggulangan

Dalam merancang, mempersiapkan, menguji dan mengimplementasikan sistem membutuhkan satuan waktu dalam priode tertentu sehingga dapat berjalan dengan benar, berikut adalah tahapan dalam pengembangan sistem tersebut yaitu :

\section{a. Metode Pengumpulan Data}

Adapun penjelasan mengenai metode yang digunakan penulis dalam menyusun Laporan Skripsi ini sebagai berikut :

1. Metode Observasi, merupakan cara pengumpulan data dimana penulis harus melakukan pengamatan secara langsung di SMKN 2 Tangerang sebagai lokasi penelitian.

2. Metode Wawancara, merupakan teknik pengumpulan data yang dilakukan melalui tatap muka dan tanya jawab langsung antara pengumpul data maupun peneliti terhadap narasumber atau sumber data. Wawancara pada penelitian sampel besar biasanya hanya dilakukan sebagai studi pendahuluan karena tidak mungkin menggunakan wawancara pada 1000 responden, sedangkan pada sampel kecil teknik wawancara dapat diterapkan sebagai teknik pengumpul data.

3. Metode Studi Pustaka, metode yang dilakukan oleh peneliti untuk dapat memperoleh informasi yang berkaitan dengan masalah yang diteliti. Informasi ini diperoleh dari buku, jurnal, laporan penelitian, dan sumber-sumber lainnya.

\section{b. Metode Analisa}

Analisis data merupakan salah satu langkah penting dalam rangka memperoleh temuantemuan hasil penelitian. Hal ini disebabkan, data akan menuntun kita ke arah temuan ilmiah, bila dianalisis dengan teknik-teknik yang tepat. Analisis sistem dilakukan menggunakan Metode Analisa Backward Chaining, yaitu Proses pencarian dimulai dari tujuan dan kesimpulan yang menjadi solusi permasalahan yang dihadapi. Mesin inferensi mencari kaidah-kaidah dalam basis pengetahuan yang kesimpulannya merupakan solusi yang ingin dicapai, kemudian dari kaidah-kaidah yang diperoleh, masing-masing kesimpulan dirunut balik jalur yang mengarah ke kesimpulan tersebut. Jika informasi- 
informasi atau nilai dari atribut-atribut yang mengarah ke kesimpulan tersebut sesuai dengan data yang diberikan maka kesimpulan tersebut merupakan solusi yang dicari, jika tidak sesuai maka kesimpulan tersebut bukan merupakan solusi yang dicari. Runut balik memulai proses pencarian dengan suatu tujuan sehingga strategi ini disebut juga goaldriven.

\section{c. Metode Perancangan}

Dalam penelitian ini metode perancangan yang digunakan adalah program Draw.io untuk menggambarkan Flowchart, dalam hal pembuatan sistem ini peneliti menggunakan Microsoft Visual Basic 6.0 sebagai penulisan program dan Microsoft Access sebagai database.

\section{d. Metode Pengembangan}

Setelah proses pengumpulan data dilakukan dengan menggunakan beberapa teknik, maka data yang sudah ada akan diolah dan dianalisis agar memberikan hasil akhir yang bermanfaat bagi penelitian ini. Penulis melakukan metode berorientasi objek pada laporan skripsi ini. Dalam metode sistem pakar, dilakukan melalui tiga (3) tahap yaitu :

1. Survey terhadap sistem yang sedang berjalan. Mengumpulkan data dan informasi langsung dari tempat penelitian, yang dilakukan dengan cara melihat sistem yang sedang berjalan dan interview atau wawancara langsung dengan staff yang berkaitan dengan penelitian.

2. Analisis terhadap temuan survey, melakukan analisa terhadap hasil yang diperoleh dari survey yang telah dilakukan.

3. Identifikasi temuan survey, mengidentifikasikan dan menanyakan kebutuhan informasi yang diperlukan guna menunjang kegiatan pembelajaran.

\section{e. Metode Pengujian}

Dalam skripsi ini metode pengujian yang digunakan yaitu Blackbox Testing. Blackbox Testing adalah metode uji coba yang memfokuskan pada keperluan software. Karena itu uji coba blackbox memungkinkan pengembang software untuk membuat himpunan kondisi input yang akan melatih seluruh syarat-syarat fungsional suatu program. Metode pengujian blackbox berusaha untuk menemukan kesalahan dalam beberapa kategori, diantaranya:fungsi-fungsi yang salah atau hilang, kesalahan interface, kesalahan dalam struktur data atau akses database eksternal, kesalahan performa, kesalahan inisialisasi, dan terminasi.

\section{LITERATURE REVIEW}

1. sistem pengganti air berdasarkan kekeruhan dan pemberi pakan ikan pada akuarium air tawar secara otomatis berbasis mikrokontroler atmega 16, 2013, Malang, adalah salah satu judul Jurnal yang di buat oleh Budi Santoso, Agung Dwi Arfianto, selaku mahasiswa STMIK Asia Malang. Penelitian ini menjelasan tentang sistem pengganti air berdasarkan kekeruhan dan pemberi pakan ikan pada akuarium air tawar secara otomatis berbasis mikrokontroler atmega 16.

2. Studi kualitas perairan sebagai alternatif pengembangan budidaya ikan di sungai keureuto kecamatan lhoksukon kabupaten aceh utara provinsi nanggroe aceh darussalam, 2012, Sumatra Utara, adalah salah satu judul Jurnal yang dibuat oleh Khairatun Nisa, Zulkifli Nasution, Khadijah EL Ramija, selaku mahasiswa Universitas Sumatera Utara. Penelitian ini menjelaskan tentang Studi kualitas perairan sebagai 
alternatif pengembangan budidaya ikan di sungai keureuto kecamatan lhoksukon kabupaten aceh utara.

3. Aplikasi teknologi aquaponic pada budidaya ikan air tawar untuk optimalisasi kapasitas produksi, 2012, Ponorogo adalah salah satu judul Jurnal yang dibuat oleh Ristiawan Agung Nugroho, Lilik Teguh Pambud, Diana Chilmawati selaku mahasiswa Universitas Diponegoro. Penelitian ini menjelaskan tentang Aplikasi teknologi aquaponic pada budidaya ikan air tawar untuk optimalisasi kapasitas produksi.

4. Otomatisasi sistem pengolahan air laut menjadi air tawar dengan prinsip reverse osmosis berbasis mikrokontroler, 2013, Surabaya adalah salah satu judul Jurnal yang dibuat oleh Renny Rakhmawati, ST.MT, Ir.Hendik Eko HS, MT, M.Zainuddin selaku Dosen Politeknik Elektronika Negeri Surabaya. Penelitian ini menjelaskan tentang pembelajaran Otomatisasi sistem pengolahan air laut menjadi air tawar dengan prinsip reverse osmosis berbasis mikrokontroler.

5. Alat penyaringan air kotor menjadi air bersih menggunakan mikrokontroller atmega 32, 2014, Bengkulu, adalah salah satu judul Jurnal yang dibuat oleh Diko Susanto, Toibah Umi Kalsum, Yanolanda Suzantri H, selaku mahasiswa Universitas Dehasen Bengkulu. Penelitian ini menjelaskan tentang Alat penyaringan air kotor menjadi air bersih menggunakan mikrokontroller atmega 32.

\section{KESIMPULAN}

Berikut kesimpulan perihal rumusan masalah mengenai Sistem Pakar Diagnosa Penyakit Ikan Hias Air Tawar Untuk Metode Pembelajaran Pada Smk Negri 2 Tangerang adalah sebagai berikut:

1. Cara mendeteksi penyakit ikan hias air tawar dalam metode pembelajaran pada siswa SMK Negeri 2 Tangerang masih berjalan secara manual dengan cara siswa berkonsultasi kepada guru dibidangnya, dan memeriksakan ikan tersebut kelaboratorium.

2. Solusi dan penanganan penyakit ikan hias air tawar melalui beberapa pertanyaan gejala penyakit kemudian sistem memberikan solusi dalam membantu proses pembelajaran bagi siswa SMK Negeri 2 Tangerang.

3. Sistem pakar ini dirancang melalui pengumpulan data berupa gejala penyakit, jenis penyakit dan cara penanggulangan dari pakar dan referensi yang didapatkan kemudian diimplementasikan sehingga dapat menghasilkan suatu sistem yang dapat mempermudah mendeteksi penyakit ikan hias air tawar bagi para siswa SMK Negeri 2 Tangerang sebagai metode pembelajaran.

\section{DAFTAR PUSTAKA}

[1] Dahria. Muhammad. 2011. Pengembangan Sistem Pakar Dalam Membangun Suatu Aplikasi. Medan: STMIK Triguna Dharma. Vol. 10, No. 3, September 2011.

[2] Hidayat. Rudi. 2013. Go To VB6. Tangerang: STMIK Raharja. Mangkulo. Alexander. Hengky. 2010. Microsoft Access 2010 Untuk Pemula. Jakarta: PT Elex Media Komputindo.

[3] Mustafa. Yudha. Bakti. 2013. Perancangan Sistem Pakar Untuk Diagnosa Waste Coating pada Mesin Coating PT Osram Indonesia. Tangerang: STMIK Raharja.

[4] Prasetio. Adhi. 2012. Buku Pintar Pemrograman Web. Jakarta : Mediakita 
[5] Saputra. Alhadi. 2012. Kajian Kebutuhan Perangkat Lunak Untuk Pengembangan Sistem Informasi Dan Aplikasi Perangkat Lunak Buatan LAPAN Bandung. Bandung: LAPAN.

[6] Semiawan. Conny. R. 2010. Metode Penelitian Kualitatif. Jakarta: Grasindo.

[7] Sutabri. Tata. 2012. Konsep Sistem Informasi. Yogyakarta: Andi.

[8] Sutarman.2012. Pengantar Teknologi Informasi. Jakarta: Bumi Aksara. Kusrini. 2010. Sistem Pakar Teori Dan Aplikasi. Yogyakarta: Andi.

[9] Sulindawati, dan Muhammad Fathoni. 2010. Pengantar Analisa Perancangan “Sistem". Medan: STMIK Triguna Dharma. Vol. 9, No. 2, Agustus 2010.

[10] Syahril. Muhammad. 2011. Konversi Data training tentang penyakit hipertensi menjadi bentuk pohon keputusan dengan teknik klasifikasi menggunakan tools rapid miner 4.1. Medan: STMIK Triguna Dharma. Vol. 10, No. 2, Mei 2011.

[11] Tiara. Khanna. 2013. Sistem Monitoring Inventory Control Pada Cv. Cihanjuang Budi Jaya. Tangerang: STMIK Raharja.

[12] Yakub. 2012. Pengantar Sistem Informasi. Yogyakarta: Graha Ilmu.

[13] Yuniarti. Evi, dkk. 2012. Kinerja Laporan Keuangan Untuk Pengambilan Keputusan Pemberian Kredit Modal Kerja. Lampung: Politeknik Negeri Lampung. 